Tang Junyi

Thomas Fröhlich - 9789004330139 Downloaded from Brill.com04/26/2023 07:19:36AM via free access 


\title{
Modern Chinese Philosophy
}

\author{
Edited by \\ John Makeham (La Trobe University)
}

VOLUME 13

The titles published in this series are listed at brill.com/mcp 


\section{Tang Junyi}

Confucian Philosophy and the Challenge of Modernity

By

Thomas Fröhlich

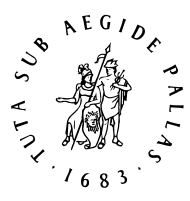

B R I L L

LEIDEN | BOSTON 


\section{B R I L L \\ OPE N}

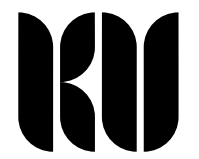

This is an open access title distributed under the terms of the CC-BY-NC License, which permits any non-commercial use, distribution, and reproduction in any medium, provided the original author(s) and source are credited.

An electronic version of this book is freely available, thanks to the support of libraries working with Knowledge Unlatched. More information about the initiative can be found at www.knowledgeunlatched.org.

The Library of Congress Cataloging-in-Publication Data is available online at http://catalog.loc.gov LC record available at http://lccn.loc.gov/2017008196

Typeface for the Latin, Greek, and Cyrillic scripts: “Brill”. See and download: brill.com/brill-typeface.

ISSN 1875-9386

ISBN 978-90-04-33014-6 (hardback)

ISBN 978-90-04-33013-9 (e-book)

Copyright 2017 by Thomas Fröhlich.

This work is published by Koninklijke Brill NV. Koninklijke Brill NV incorporates the imprints Brill, Brill Hes \& De Graaf, Brill Nijhoff, Brill Rodopi and Hotei Publishing.

Koninklijke Brill NV reserves the right to protect the publication against unauthorized use and to authorize dissemination by means of offprints, legitimate photocopies, microform editions, reprints, translations, and secondary information sources, such as abstracting and indexing services including databases. Requests for commercial re-use, use of parts of the publication, and/or translations must be addressed to Koninklijke Brill NV.

This book is printed on acid-free paper and produced in a sustainable manner. 


\section{Contents}

Preface and Acknowledgments VII

1 Tang Junyi's Intellectual Endeavor 1

A Journey into a Broken World 1

The Vantage Point of Modern Confucianism 7

The Watershed of $1949 \quad 18$

2 Critical Issues in Research on Modern Confucianism 23

Stereotypes and Omissions 23

Coherence and Comparison 31

3 Common Perspectives on Tang Junyi's Thought 43

Conservatism 43

Neo-Confucianism 46

Humanism and Religiosity 48

Dogmatism 53

4 Exile, Modernity, and Cultural Patriotism 61

The Convergence between Exile and Modernity 61

Exile as Horror Vacui $\quad 69$

Intellectual Ethos and Messianic Vision $\quad 76$

Nation and Culture 85

Cultural Patriotism 93

Defending Authenticity 100

5 The Theological Accentuation 108

Theological Foundations 108

The Taxonomy of Knowledge and Intuition $\quad 118$

Limits of Philosophical Exposition 124

The Limit-Concepts of "Philosophical Faith" 130

6 The Moral Vision 138

Moral Intuitionism $\quad 138$

Struggling with "Self-Cultivation" 144

Outlines of a Confucian Ethos 154 
$7 \quad$ Shifting the Foundations of Confucian Political Thought 161

The Political and Its Demonic Aspects 161

Introspection in the Will for Power 170

The Moral Dimension of the Political Will 178

$8 \quad$ On Statehood 182

Failed Statehood in China 182

The State and Individual Self-Fulfillment $\quad 189$

State and Society 193

The World Order of "Ecumenical States" 198

$9 \quad$ Anticipating Democracy 206

"Confucian Democracy": Dead Ends and Alternatives 206

The Weakness of Democracy in China 215

The Civil-Theological Justification of Democracy 220

Humanistic Culture and Democracy 228

10 Civil Religion on a Confucian Basis 240

Civil Religion for a Future China 240

Political Ideals and Reality 247

11 Coming to Terms with History 250

Modernity and Agency 250

History and Normativity $\quad 257$

Signs of Progress 264

Delimiting a "Philosophy of History" $\quad 267$

12 In Lieu of a Conclusion: The Totalitarian Challenge 270

On the Origins and Causes of Totalitarianism 271

Overcoming Totalitarianism? 281

Appendix: Biographical Survey 291

Bibliography 293

Index 314 


\section{Preface and Acknowledgments}

The present book on Tang Junyi attempts to make his work accessible for contemporary philosophy and intellectual history. Although I have interpreted Tang's works as an intellectual historian, I endeavor here to do more than think about him. I also think with Tang and, consequently, at times go beyond him.

It is admittedly not the case that all of Tang's oeuvre equally deserves contemporary philosophy's undivided attention. Indeed, some parts are best left to intellectual historians. Their examination can deepen our historical understanding of modern Confucianism, without necessarily having immediate relevance for current discussions in international philosophy or political theory. Other parts, however, undoubtedly offer stimulating insights with respect to ongoing discourses, for example on modernity, in these disciplines.

The scope of the subject matter covered by Tang's philosophy is vast. Readers can thus follow their own interests by perusing specific chapters. For those with little interest in political ideas and historical thinking, Chapters 8 to 12 are of secondary importance. As regards the first three chapters, and Chapters 5 and 6, they offer an examination of the historical and intellectual contexts of Tang's Confucianism, as well as an analysis of the civil-theological framework, which is crucial for understanding his philosophical undertaking. Chapter 7 should also be of interest for those readers who do not normally study political philosophy. It shows how profoundly Tang's thought differs from common, often uninspiring interpretations of Confucianism and its idea of man. In the same vein, Chapter 4 is meant to correct the impression that Confucians of the 2oth century mostly contented themselves with defending "Chinese culture" and fighting cultural battles against Western influence. The fact that Tang was more concerned with general problems of modern life and exile is one of the reasons why his work rewards careful study.

Finally, it is not my aim to reconstruct Tang Junyi's philosophy as a closed system free from inner contradictions. This would inevitably lead to ommissions and misrepresentations of certain parts of his work. Nor do I wish to present a hermetic exegesis of his writings that would have little more to offer than a straightforward reading of his texts.

Research on the present work began more than fifteen years ago. Some parts have been published, in earlier versions, as articles in journals and collective volumes. Chapter 4 is based on my "The Exilic Prism of Modernity: New Perspectives on the Post-War Philosophy of Tang Junyi;" Chapters 7 and 8 contain some revised passages from "Tang Junyi, Max Weber und die Mächte des Dämonischen. Zum Politikverständnis eines modernen Konfuzianers," and 
"Tang Junyi und die konfuzianische Erneuerung des chinesischen Staates;" Chapter 9 entails revised passages of "'Confucian Democracy' and its Confucian Critics: Mou Zongsan and Tang Junyi on the Limits of Confucianism;" Chapters 11 and 12 contain parts of "The Challenge of Totalitarianism: Lessons from Tang Junyi's Political Philosophy."

I wish to thank the German Federal Ministry of Education and Research for funding the International Consortium for the Research in the Humanities: Fate, Freedom, and Prognostication. Strategies of Coping with the Future in East Asia and Europe (at the University of Erlangen-Nuremberg). This research project gave me the opportunity, as one of its directors, to work on this book in an inspiring intellectual environment. The same applies to the visiting professorship at the University of Hamburg, where I finished the manuscript. I am sincerely grateful to the colleagues from Sinology at the University of Hamburg for inviting me to their institute.

I am indebted to many colleagues for their support over the years. Professors Sébastien Billioud (Paris Diderot), Stéphane Feuillas (Paris Diderot), Michael Friedrich (Hamburg), HonTze-ki(sunY Geneseo), Huang Kuan-min(Academia Sinica, Taiwan), Lionel Jensen (Notre Dame, Colorado), Kai Marchal (Soochow University, Taiwan), Peng Guoxiang (Zhejiang University), Axel Schneider (Göttingen), Takahiro Nakajima (Tokyo University), Kai Vogelsang (Hamburg), and Ralph Weber (Basel) have either read earlier articles, parts of this book, or discussed its subject matter. Their comments and suggestions were very helpful. Tu Wei-ming (IHAs Beijing) kindly invited me along to visit the Fazhu Institute in Hong Kong, whose chairperson Huo Taohui is a former student of Tang Junyi. Other colleagues offered insightful comments on the occasion of numerous talks and at conferences where I have presented my research on Tang in recent years. I am also indebted to the book's two reviewers, Professor Jason Clower (California State University) and an anonymous reader. Their critical comments and questions were invaluable in improving the manuscript. Finally, Dr. Christopher Reid was a very reliable, but also inspiring proofreader. 